\title{
Retrospective determination of HIV-1 status by a PCR method on paraffin wax embedded sections
}

\author{
T Slavik, M Wolfaardt, $H$ van Zyl, I W Simson
}

\begin{abstract}
Aim-To develop a simple but reliable polymerase chain reaction (PCR) method to determine the HIV-1 status of patients on formalin fixed, paraffin wax embedded lymph node tissue.

Methods-Fifty lymph node specimens, 20 from HIV-1 seropositive and 30 from HIV-1 seronegative patients, were analysed. Lymph nodes with a variety of disease conditions were included in the study. Tissue sections were treated with a DNA extraction buffer containing proteinase $K$ and the crude cell lysate was used in PCR analysis. Nested primers were used to amplify HIV-1 DNA sequences coding for gag, pol and env proteins. PCR products were demonstrated by polyacrylamide gel electrophoresis. Results were then compared with HIV-1 serology of the patients from whom the tissue was obtained.

Results-The PCR method yielded a specificity of $100 \%$, a sensitivity of $95 \%$, a positive predictive value of $100 \%$, and a negative predictive value of $97 \%$ when compared with HIV-1 serology. The $\kappa$ statistic $(0.958)$ showed an excellent agreement between the PCR method and serology. Furthermore, HIV-1 DNA was demonstrated in lymph node tissue from a serologically unconfirmed acquired immunodeficiency syndrome case necropsied in 1982.

Conclusion-This PCR method is a simple and reliable means of retrospectively determining the HIV-1 status of patients using formalin fixed, paraffin wax embedded lymph node tissue.

(f Clin Pathol 1995;48:733-736)
\end{abstract}

Keywords: HIV, PCR, paraffin wax section, lymph node.

Department of Anatomical Pathology, Faculty of Medicine, University of Pretoria, P.O. Box 2034, Pretoria, South Africa T Slavik

I W Simson

Department of Medical Virology M Wolfaardt

$\mathrm{H}$ van $\mathrm{Zyl}$

Correspondence to: Dr T Slavik.

Accepted for publication 20 December 1994
The polymerase chain reaction (PCR) amplifies viral genetic material and has been widely used for detecting HIV-1 infection. ${ }^{3}$ A potential problem with the sensitivity of PCR is contamination of the sample or reagents which can lead to false positive results. Such false positive results can, however, be avoided by simple protocols for sample preparation and strict laboratory routines. Various pre-treatment techniques for processing formalin fixed, paraffin wax embedded specimens have been described, ${ }^{4-8}$ but they are relatively complicated, expensive or cause significant DNA loss due to many manipulations.

This study was conducted to develop and evaluate a simple but reliable method to determine the HIV-1 status of patients using formalin fixed, paraffin wax embedded tissue. Paraffin wax sections of lymph nodes were used for detection of viral DNA as they carry a high viral load in HIV-1 infection. ${ }^{9}$

\section{Methods}

Fifty formalin fixed, paraffin wax embedded lymph node specimens, including 20 from HIV-1 seropositive and 30 from HIV-1 seronegative patients, were selected. Both the seropositive and control seronegative groups included lymph nodes with reactive change, as well as inflammatory and neoplastic lesions (table 1). Thirty eight of the specimens were obtained antemortem and 12 postmortem. The age of the paraffin blocks varied from one to 137 months.

Between sectioning of the different specimens, the microtome knife was decontaminated with $4 \mathrm{~N} \mathrm{HCl}$ solution. Further precautions taken to minimise possible contamination included aliquoting of all reagents, physical separation of pre- and post-PCR reactions, irradiation of reagents with ultraviolet light, the inclusion of multiple negative controls, and the use of nested PCR primers. Gloves were worn during all procedures when the specimens were being handled and processed.

After transferral into sterile $1 \mathrm{ml}$ tubes, the coded $10 \mu \mathrm{m}$ sections were treated with $400 \mu \mathrm{l}$ DNA extraction buffer ${ }^{10}$ containing $50 \mathrm{mM}$ $\mathrm{KCl}, 10 \mathrm{mM}$ Tris, $2.5 \mathrm{mM} \mathrm{MgCl} 2,0 \cdot 1 \mathrm{mg} / \mathrm{ml}$ gelatin, $0.45 \%$ Nonidet $\mathrm{P} 40,0.45 \%$ Tween20 , and $20 \mu 110 \mathrm{mg} / \mathrm{ml}$ proteinase $\mathrm{K}$ for eight hours at $56^{\circ} \mathrm{C}$. The reaction was stopped by boiling for eight minutes. Five microlitres of this crude cell lysate were used for the PCR. form of formalin fixed, paraffin wax embedded blocks, but retrospective studies are hampered because the HIV-1 status of the patients is often unknown. malignancies constituting the acquired imof the pathology of these diseases and precise association with HIV-1 infection is often limited by the lack of fresh material. Many 
Table 1 Study cases with histological diagnosis, specimen information and results

\begin{tabular}{|c|c|c|c|c|c|}
\hline Specimen number & Histological diagnosis & $\begin{array}{l}\text { Tissue obtained antel } \\
\text { postmortem }\end{array}$ & $\begin{array}{l}\text { Age of paraffin wax } \\
\text { block (in months) }\end{array}$ & HIV serology & $P C R$ result \\
\hline 1 & Reactive change & Post & 12 & - & - \\
\hline 2 & Reactive change & Post & 12 & - & - \\
\hline 3 & Reactive change & Post & 11 & - & - \\
\hline 4 & Reactive change & Ante & 4 & - & - \\
\hline 5 & Reactive change & Ante & 4 & - & - \\
\hline 6 & Reactive change & Ante & 3 & - & - \\
\hline 7 & Reactive change & Ante & 3 & - & - \\
\hline 8 & Reactive change & Ante & 2 & - & - \\
\hline 9 & Reactive change & Ante & 2 & - & - \\
\hline 10 & Reactive change & Ante & 1 & - & - \\
\hline 11 & Tuberculous lymphadenitis & Ante & 12 & - & - \\
\hline 12 & Tuberculous lymphadenitis & Ante & 15 & - & - \\
\hline 13 & Tuberculous lymphadenits & Ante & 11 & - & - \\
\hline 14 & Tuberculous lymphadenitis & Ante & 20 & - & - \\
\hline 15 & Tuberculous lymphadenitis & Ante & 17 & - & - \\
\hline 16 & Tuberculous lymphadenitis & Ante & 22 & - & - \\
\hline 17 & Tuberculous lymphadenitis & Ante & 20 & - & - \\
\hline 18 & Tuberculous lymphadenitis & Ante & 22 & - & - \\
\hline 19 & Tuberculous lymphadenitis & Ante & 26 & - & - \\
\hline 20 & Tuberculous lymphadenitis & Ante & 20 & - & - \\
\hline 21 & Sarcoidosis & Ante & 40 & - & - \\
\hline 22 & Sarcoidosis & Ante & 29 & - & - \\
\hline 23 & Sarcoidosis & Ante & 27 & - & - \\
\hline 24 & Sarcoidosis & Ante & 7 & - & - \\
\hline 25 & Metastatic ganglioneuroblastoma & Ante & 4 & - & - \\
\hline 26 & Metastatic breast carcinoma & Ante & 2 & - & - \\
\hline 27 & Metastatic neuroendocrine carcinoma & Ante & 5 & - & - \\
\hline 28 & Hodgkin's lymphoma & Ante & 2 & - & - \\
\hline 29 & Hodgkin's lymphoma & Ante & 1 & - & - \\
\hline 30 & T cell lymphoblastic lymphoma & Ante & 1 & - & - \\
\hline 31 & Reactive change & Post & 22 & + & + \\
\hline 32 & Reactive change & Post & 40 & + & + \\
\hline 33 & Reactive change & Post & 116 & + & + \\
\hline 34 & Reactive change & Post & 137 & + & + \\
\hline 35 & Reactive change & Ante & 6 & + & + \\
\hline 36 & Reactive change & Ante & 5 & + & + \\
\hline 37 & Reactive change & Ante & 49 & + & + \\
\hline 38 & Reactive change & Ante & 3 & + & + \\
\hline 39 & Reactive change & Ante & 3 & + & + \\
\hline 40 & Histoplasmosis & Post & 31 & + & + \\
\hline 41 & Histoplasmosis & Post & 118 & + & + \\
\hline 42 & Measles & Post & 61 & + & + \\
\hline 43 & Cryptococcosis & Post & 59 & + & + \\
\hline 44 & Tuberculous lymphadenitis & Ante & 6 & + & - \\
\hline 45 & Tuberculous lymphadenitis & Ante & 10 & + & + \\
\hline 46 & Tuberculous lymphadenitis & Ante & 10 & + & + \\
\hline 47 & Tuberculous lymphadenitis & Ante & 2 & + & + \\
\hline 48 & Tuberculous lymphadenitis & Ante & 4 & + & + \\
\hline 49 & Tuberculous lymphadenitis & Ante & 2 & + & + \\
\hline 50 & Kaposi’s sarcoma & Post & 79 & + & + \\
\hline
\end{tabular}

The PCR was performed using oligonucleotide primer pairs JA9/12 (nested JA10/11), JA17/20 (nested JA18/19) and GAG1/2 (nested GAG3/ 4) (synthesised by the Department of Biochemistry, University of Cape Town, Cape Town, South Africa) to amplify fragments of DNA from the envelope, polymerase and p24 regions of HIV-1. ${ }^{112}$ The PCR was performed in a two-step reaction, first with a pair of outer primers and then with a pair of inner nested primers. The reaction mixtures contained $100 \mathrm{mM}$ Tris- $\mathrm{HCl}(\mathrm{pH} 8.3), 40 \mathrm{mM} \mathrm{KCl}$, $\mathrm{MgCl}_{2}$ (3 mM for primer pair JA10/11, JA18/ 19, GAG1/2, and GAG3/4, $4 \mathrm{mM}$ for primer pair JA9/12 and $7 \mathrm{mM}$ for JA17/20)(final concentrations), each primer at $0.1 \mu \mathrm{M}, 0.5 \mathrm{mM}$ dNTPs, and 1 unit Taq polymerase per $50 \mu \mathrm{l}$ (Boehringer Mannheim, Mannheim, Germany). In addition, lysates were amplified with human $\beta$-globin primers PCO3/PCO4 as an internal control. ${ }^{13}$

The samples were denatured for five minutes at $94^{\circ} \mathrm{C}$, then cycled 30 times at $95^{\circ} \mathrm{C}$ for two minutes, annealed at $40^{\circ} \mathrm{C}$ for 30 seconds (gag and pol primer pairs) or $50^{\circ} \mathrm{C}$ for 30 seconds (env primer pairs), and extended at $72^{\circ} \mathrm{C}$ for two minutes. After the first PCR, $5 \mu \mathrm{l}$ of the product was amplified for 30 cycles with the corresponding inner primers. The final PCR product was visualised by polyacrylamide gel electrophoresis and ethidium bromide staining.
The HIV-1 PCR result was taken as positive if DNA from two of the three regions was amplified. PCR results were then compared with the HIV-1 serology determined at the time that the lymph node specimen was taken. Two enzyme linked immunosorbent assay (ELISA) HIV antibody tests (Vironostika Mixt, Organon Teknika Corp., Durham, North Carolina, USA, and Wellcozyme HIV $1+2$, Wellcome Diagnostics, Dartford, UK) were used and positive results were confirmed by means of a western blot (HIV Blot 2.2, Diagnostic Biotechnology Pty Ltd., Singapore) and recombinant immunoblot assay (Pepti-Lav, Diagnostics Pasteur, Marnes-La-Coquette, France).

\section{Results}

The comparison between PCR results and serology is shown in table 2. There was excellent agreement between these two methods ( $\kappa$ statistic of 0.958$)$. When compared with HIV-1

Table 2 Correlation of HIV-1 serology and PCR results

\begin{tabular}{llcl}
\hline Serology & $P C R$ positive & $P C R$ negative & Total \\
\hline Positive & 19 & 1 & 20 \\
Negative & 0 & 30 & 30 \\
Total & 19 & 31 & 50 \\
\hline
\end{tabular}


serology, the PCR technique had a specificity of $100 \%(30 / 30)$, a sensitivity of $95 \%(19 / 20)$, a negative predictive value of $97 \%(30 / 31)$ and a positive predictive value of $100 \%(19 / 19)$.

Table 1 illustrates the age of the paraffin wax blocks and whether the specimen was obtained ante- or postmortem.

\section{Discussion}

Of the 30 specimens obtained from HIV-1 seronegative patients, all proved to be negative by the PCR technique. Two of these specimens demonstrated a single HIV-1 DNA sequence (one gag and one pol) considered to be due to possible cross contamination with other samples. ${ }^{14}{ }^{15}$ Extensive precautions were taken to prevent pre-PCR contamination, but postPCR carry-over remains a possibility. This could have been eliminated had a uracil $\mathrm{N}$ glycosylase prevention strategy been used. ${ }^{16}$

Nineteen of the 20 specimens obtained from HIV-1 seropositive patients were positive by PCR. Fifteen demonstrated all three HIV-1 DNA sequences. Of the remaining four specimens, three lacked pol and one lacked env DNA sequences. One of the specimens (specimen no. 44 ), an extremely small lymph node fragment obtained by needle biopsy from an HIV-1 seropositive patient, did not demonstrate any HIV-1 DNA products by PCR. A recent report has documented the occurrence of false positive HIV-1 serology in leprosy patients, possibly due to cross reactivity between HIV-1 proteins and mycobacterial cell wall antigens. ${ }^{17} \mathrm{Al}-$ though the histological diagnosis of this specimen was tuberculous lymphadenitis, the presence of antibodies to all three HIV-1 env proteins on the patient's western blot makes this an unlikely explanation, as cross reactivity with mycobacterial antigens appears to be limited to HIV-1 gag, pol and gp41 proteins.

In practice, a critical quantity of DNA is needed for successful amplification by PCR $^{11418}$ which could explain the false negative PCR result, as the specimen was extremely small. This was confirmed by a negative result after DNA precipitation of the proteinase $\mathrm{K}$ digest prior to PCR. Subsequent testing with larger quantities of tissue was not possible as there was no more tissue in the block.

The superior analytical sensitivity of the PCR technique over HIV-1 serology is well documented. ${ }^{19}$ This was observed in our study in a patient (specimen no. 39) who was undergoing seroconversion at the time of lymph node biopsy. An HIV-1 ELISA test done on this patient eight days prior to biopsy was negative. HIV-1 serology repeated seven days later yielded a positive ELISA test and an indeterminate western blot (only gp 160 present). PCR carried out on the lymph node biopsy performed the following day demonstrated all three HIV-1 DNA products. Serology done 11 days after biopsy revealed a positive ELISA test with p24, p31, gp120, and gp 160 bands present on the western blot. Retrospective determination of p24 antigen yielded positive results on both serum specimens drawn prior to biopsy.
Although DNA fragmentation in specimens increases with time and this can lead to false negative PCR results, ${ }^{20}$ we did not experience this problem in our study. PCR demonstration of all three HIV-1 DNA products was possible in a lymph node specimen more than 11 years (137 months) old. All three DNA products were also demonstrated in lymph node tissue 141 months old obtained from a case diagnosed as AIDS but never confirmed serologically, which was necropsied in our department in August 1982.

In spite of the low number of cases this study shows that this PCR technique is a reliable and relatively simple method of retrospectively determining HIV-1 status using formalin fixed, paraffin wax embedded tissue. Furthermore, using this method it is possible to detect early cases of HIV-1 infection before seroconversion occurs, as the method detects proviral DNA rather than an antibody response.

With techniques such as immunocytochemistry, in situ hybridisation and PCR being used in many laboratories, much study has been undertaken of the pathogenesis and histopathology of HIV-1 infection using tissue sections. The correlation of various pathological changes and HIV-1 positivity has provided important information with regard to the progression of HIV-1 infection to AIDS.

The shortage of tissue specimens, however, remains a problem. Fresh tissue is scarce and retrospective analysis of more abundant archival material is hampered by the fact that many of these specimens come from patients whose HIV-1 status is unknown. Using this PCR method, we have been able to determine retrospectively the HIV-1 status of archival tissue for research purposes.

1 Selik RM, Starcher ET, Curran JW. Opportunistic diseases reported in AIDS patients: frequencies, associations and reported in AIDS patients: frequ
trends. $A I D S$ 1987;1:175-82.

2 Levine AM. Non-Hodgkin's lymphomas and other malignancies in the acquired immunodeficiency syndrome. Cancer 1987;60:719-23.

3 Giri AA, Lillo FB, McDermott JL, Jannuzzi C, Risso S, Fornia $\mathrm{G}$, et al. Detection of HIV-1 sequences in children using radioactive and colorimetric polymerase chain reactions. F Med Virol 1994;42:414-19.

4 Kiene P, Milde-Langosch K, Runkel M, Schulz K, Loning $T$. A simple and rapid technique to process formalin-fixed, paraffin-embedded tissues for the detection of viruses by the polymerase chain reaction. Virchows Arch A Pathol the polymerase chain reaction. Vir
Anat Histopathol 1992;420:269-73.

5 Barton-Rogers B, Alpert LC, Hine EA, Buffone G. Analysis of DNA in fresh and fixed tissue by the polymerase chain reaction. Am $\mathcal{F}$ Pathol 1990;136:541-8.

6 Jackson DP, Lewis FA, Taylor GR, Boylston AW, Quirke $P$. Tissue extraction of DNA and RNA and analysis by the polymerase chain reaction. $f$ Clin Pathol 1990;43: 499-504.

7 Kiyabu MT, Shibata D, Arnheim N, Martin WJ, Fitzgibbons PL. Detection of human papillomavirus in formalin-fixed, invasive squamous carcinomas using the polymerase chain invasive squamous carcinomas using the polym

reaction. Am f Surg Pathol 1989;13:221-4.
8 Shibata DK, Arnheim N, Martin WJ. Detection of human papillomavirus in paraffin-embedded tissue using the polymerase chain reaction. $\mathcal{F}$ Exp Med 1988;167:225-30.

9 Fox CH, Hoover S, Curral VR, Bahre HJ. HIV in infected lymph nodes [letter]. Nature 1994;370:256.

10 Smith SA, Easton DF, Evans DGR, Ponder BAJ. Allele losses in the region 17q12-21 in familial breast and ovarian cancer involve the wild-type chromosome. Nature Genet 1992; 2:128-31.

11 Albert J, Fenyö EM. Simple, sensitive, and specific detection of human immunodeficiency virus type 1 in clinical specimens by polymerase chain reaction with nested primers. f Clin Microbiol 1990;28:1560-4.

$12 \mathrm{Kemp}$ AJ, Smith CB, Foote SJ, Samaras N, Peterson MG. Colorimetric detection of specific DNA segments amplified by polymerase chain reactions. Proc Natl Acad Sci lified by polymerase chain $1989 ; 86: 2423-7$.

13 Saiki RK, Gelfand DH, Stoffel S, Scharf SJ, Higuchi R, Horn GT, et al. Primer-directed enzymatic amplification 
of DNA with a thermostable DNA polymerase. Science 1988;239:487-91.

14 Bootman JS, Kitchin PA. An international collaborative study to assess a set of reference reagents for HIV-1 PCR. ftudy to assess a sethods 1992;37:23-42.

15 Defer C Ant $\mathrm{F}$, Vignon D, et al. Multicentre quality control of polymerase chain reaction for detection of HIV DNA. AIDS 1992;6:659-63.

16 Longo MC, Berninger MS, Hartley JL. Use of uracil DNA glycosylase to control carry-over contamination in PCR. Gene 1990;93:125-8

17 Kashala O, Marlink R, Ilunga M, Diese M, Gormus B, Xu $\mathrm{K}$, et al. Infection with human immunodeficiency virus type $1(\mathrm{HIV}-1)$ and human $\mathrm{T}$ cell lymphotropic viruses among leprosy patients and contacts: correlation between HIV-1 cross-reactivity and antibodies to lipoarabinomannan. F Infect Dis 1994;169:296-304.

18 Krivine A, Firtion G, Cao L, Francoual C, Hention R, Lebon P. HIV replication during the first weeks of life. Lancet 1992;339:1187-9.

19 Sönnerborg A, Abens J, Johansson B, Strannegard Ö. Detection of human immunodeficiency virus-1 by polymerase chain reaction and virus cultivation. 7 Med Virol 1990;31: 234-40.

20 Pääbo S. Ancient DNA: extraction, characterization, molecular cloning, and enzymatic amplification. Proc Natl Acad Sci USA 1989;86:1939-43. 